\title{
How can we best detect atrial fibrillation?
}

\author{
${ }^{1} \mathrm{~K}$ Harris, ${ }^{2} \mathrm{D}$ Edwards, ${ }^{3} \mathrm{~J}$ Mant \\ ${ }^{1}$ Academic Clinical Fellow; ${ }^{2}$ Clinical Research Associate; ${ }^{3}$ Professor; General Practice \& Primary Care Research Unit, Strangeways Research \\ Laboratory, University of Cambridge, Cambridge, UK
}

\section{ABSTRACT}

Atrial fibrillation (AF) is an arrhythmia of increasing prevalence associated with a reducible risk of stroke. We conducted a systematic review to address five questions relating to how we can best detect AF:

I. Are there useful screening tests to determine who should have a I 2-lead electrocardiogram (ECG)? Potential screening tests, all with acceptable sensitivity, include pulse palpation, single-lead ECG and newer technologies such as modified sphygmomanometers or a finger probe device. Pulse palpation has a high number of false positives, but is the cheapest method.

2. Is it more effective to offer I2-lead ECGs to the whole population (or specific sub-groups) or only to those who screen positive for AF? The cost-effectiveness of new devices, such as a modified blood pressure monitor, needs to be assessed. It is more cost-effective to opportunistically screen people rather than to offer a I2-lead ECG to everybody.

3. How accurate are different healthcare professionals and interpretative software at diagnosing AF on ECG? Definitive diagnosis of AF should be by 12-lead ECG, interpreted by someone with appropriate expertise. Computer software is not currently sensitive enough to be used alone to diagnose AF on ECG. Primary care practitioners may not accurately detect AF on ECG, but consistently high accuracy can be achieved by healthcare professionals with adequate training.

4. How best can we diagnose paroxysmal atrial fibrillation (PAF)? In patients in whom PAF is suspected, longer periods of monitoring will detect more cases of PAF.

5. What is the impact of the use of different ECG monitoring strategies (e.g. Holter monitoring, serial ECGs, continuous ECG) on AF detection rates post-stroke? In patients post-stroke, a single ECG will miss cases of PAF which can be detected by longer duration monitoring such as Holter monitoring, cardiac event recorders and serial ECGs. Further research into the cost-effectiveness of these methods, the duration of monitoring required and the clinical significance of the PAF detected is needed.
Correspondence to J Mant General Practice \& Primary Care Research Unit, Strangeways Research Laboratory, University of Cambridge, Wort's Causeway, Cambridge CBI 8RN, UK

jm677@medschl.cam.ac.uk

DECLARATION OF INTERESTS Professor Mant has received consultancy fees (lapsed personal; current non-personal) from Boehringer Ingelheim. Dr Harris and Dr Edwards have no interests to declare.

\section{INTRODUCTION}

Atrial fibrillation (AF) is an arrhythmia present in around $1 \%$ of the population.' It is characterised by an irregular heartbeat and is associated with symptoms such as palpitations, chest pain, breathlessness and dizziness. On an electrocardiogram (ECG) $A F$ is characterised by an absence of consistent $P$ waves. ${ }^{2}$ The prevalence is strongly associated with age, with over $8 \%$ of people aged 65 or over in $\mathrm{AF}^{3}$ Indeed, $85 \%$ of people in AF are aged 65 or over.' AF is becoming more common, not only in association with an ageing population, but also as a result of an increase in age-specific incidence, ${ }^{4}$ likely to be due to improved survival of people with ischaemic heart disease, which is linked to the majority of cases of $A F^{5}$ The presence of $A F$ is associated with a five-fold increased risk of stroke, independent of other risk factors ${ }^{6}$ but it is often asymptomatic and the first presentation may be with a stroke. ${ }^{7}$ If $\mathrm{AF}$ is detected, the risk of stroke can be substantially reduced by oral anticoagulation, whether with vitamin $\mathrm{K}$ antagonists $(\mathrm{VKA})^{8}$ or with one of the newer anticoagulants such as dabigatran.'

The chronic forms of AF can be divided into paroxysmal AF (more than one episode with spontaneous termination within seven days, but usually within 48 hours); persistent AF (not self-terminating, or lasting more than seven days) and permanentAF (not terminated, terminated but relapsed or no cardioversion attempt made). Silent or asymptomatic AF may occur in any of 
K Harris, D Edwards, J Mant

these temporal forms, and carries a similar prognosis to symptomatic $A F^{10,11}$ About a quarter of $A F$ is paroxysmal,' which carries a similar prognosis to permanent $A F^{12}$

The accepted investigation for diagnosing permanent $\mathrm{AF}$ is a I2-lead ECG. This will only pick up paroxysmal AF if the test is performed while a paroxysm is in progress. How best to detect AF may be operationalised into a number of different research questions:

I. Are there useful screening tests to determine who should have a 12-lead ECG? Potential such tests include pulse palpation, single-lead ECGs or new technologies such as finger probes or modified blood pressure monitors.

2. Is it more effective to offer I2-lead ECGs to the whole population (or specific sub-groups) or only to those who screen positive for AF?

3. How accurate are different healthcare professionals and interpretative software at diagnosing AF on ECG?

4. How best can we diagnose paroxysmal AF?

A particular sub-group of people in whom there is particular interest in diagnosing $A F$ is in people who have had a stroke/transient ischaemic attack (TIA), since their recurrent risks of stroke are very high. While the major focus of this review is on community detection of AF, we also look at the impact of different methods of diagnosing $\mathrm{AF}$ after acute stroke, addressing the question:

5. What is the impact of the use of different ECG monitoring strategies (e.g. Holter monitoring, serial ECGs, continuous $\mathrm{ECG}$ ) on $\mathrm{AF}$ detection rates post-stroke?

\section{METHODS}

This narrative literature review uses papers cited in the 2006 NICE guidance on AF and a systematic search of Medline and Embase using the MeSH terms 'atrial fibrillation' and 'sensitivity and specificity' and 'electrocardiography' or 'pulse' or 'electrocardiography, ambulatory' or 'diagnostic techniques, cardiovascular' or 'sphygmomanometers', limiting our search to English language publications from 2006 onwards. After identifying all potentially relevant papers we then reviewed their references to find additional publications. We excluded from our search papers considering incidental detection of AF by devices such as pacemakers.

\section{DESCRIPTION OF STUDIES}

\section{I.Are there useful screening tests to determine who should have a I2-lead ECG?}

a) Pulse palpation

We found four relevant studies which were all set in UK general practices and involved pulse palpation by a practice nurse (Table I). When the assessment was for any pulse irregularity, pulse palpation was reasonably sensitive $(87 \%-97 \%)$, but not very specific $(70 \%-81 \%)$. The largest study, which involved 25 general practices and is probably the most representative of clinical practice, found the lowest sensitivity. ${ }^{13}$ In the general population, the majority (70-87\%) of people with any pulse irregularity will not have $A F$, as demonstrated by the low positive predictive values. Morgan et $\mathrm{a}^{1 / 4}$ found that specificity could be improved (and correspondingly, positive predictive value) if continuous pulse irregularity was sought, but at the cost of a big drop in sensitivity (from $91 \%$ to $54 \%$ ).

\section{b) Single-lead ECGs}

A single-lead ECG avoids the need for the patient to remove clothing and is quicker to perform than a 12-lead ECG. However, inevitably some information is lost which may lead to a reduced ability to detect AF. Our search revealed four relevant studies which are summarised in Table 2. When interpreting such studies, it is important to distinguish between the effect of using a simpler ECG, and the effect of using (as would usually be the case in clinical practice) a non-expert to interpret the trace. Who reads the ECG appears to be a much more important factor than how the reading was obtained. Thus, in the study by Mant et al ${ }^{15}$ the relatively poor results of single-lead ECGs (sensitivity of $83-85 \%$ and specificity of $87-89 \%$ when interpreted by GPs) were similar to the results obtained for 12-lead ECGs when read by GPs (Table 3). In contrast, Doliwa et al' and Somerville et $\mathrm{al}^{17}$ found high sensitivity $(92 \%$ and $96 \%$ ) and high specificity (96\% and $98 \%$ ) when a bipolar 'thumb' ECG was read by a cardiologist, and a bipolar ECG was read by an experienced GP, respectively.

\section{c) New technologies}

We found four relevant studies that considered two devices which could be used for screening for $A F$ in the general population. The studies are summarised in Table 3. The device described by Lewis et $\mathrm{a}^{18}$ is a finger probe similar to that used in general practice for pulse oximetry which uses the principle of photoplethysmography. The two studies by Wiesel et al ${ }^{19,20}$ and that by Stergiou et $\mathrm{a}^{12}$ consider a modified blood pressure monitor similar to those used by patients to monitor their blood pressure at home. This could either be used by people monitoring their own blood pressure to self-screen for AF or by primary care professionals to opportunistically screen patients. These devices benefit from the ability to modify thresholds of detection in order to achieve maximum sensitivity to optimise their value as screening devices.

In general, a screening test needs to have high sensitivity so it doesn't miss cases. The higher the specificity, the fewer people who need to have the reference standard investigation. The reference standard test in diagnosing AF, a I2-lead ECG, is readily available, non-invasive and relatively inexpensive. Its main drawbacks are that it is time consuming to use and requires some degree of 
TABLE I Studies of the accuracy of pulse palpation in the diagnosis of atrial fibrillation.

\begin{tabular}{|c|c|c|c|c|c|c|}
\hline Study & Population & $\begin{array}{l}\text { Reference } \\
\text { standard }\end{array}$ & $\begin{array}{l}\text { Method } \\
\text { being } \\
\text { tested }\end{array}$ & $\begin{array}{l}\text { Sensitivity } \\
\%(95 \% \\
\text { confidence } \\
\text { interval where } \\
\text { known) }\end{array}$ & $\begin{array}{l}\text { Specificity } \\
\%(95 \% \\
\text { confidence } \\
\text { interval where } \\
\text { known) }\end{array}$ & $\begin{array}{l}\text { Positive } \\
\text { predictive } \\
\text { value }(95 \% \\
\text { confidence } \\
\text { interval where } \\
\text { known) }\end{array}$ \\
\hline \multirow[t]{3}{*}{$\begin{array}{l}\text { Morgan et al } \\
(2001)^{14}\end{array}$} & \multirow{3}{*}{$\begin{array}{l}\text { I,099 patients aged } \\
\text { over } 65 \text { randomly } \\
\text { selected from four } \\
\text { general practices. } \\
\text { Prevalence of AF } \\
6.1 \% .^{*}\end{array}$} & \multirow{3}{*}{$\begin{array}{l}\text { Single lead (lead } \\
\text { II) rhythm strip } \\
\text { interpreted by the } \\
\text { first author, who } \\
\text { is a GP }\end{array}$} & \begin{tabular}{|l|} 
Nurse pulse \\
assessment \\
of any pulse \\
irregularity
\end{tabular} & 91 (82-97) & 74 (72-77) & $19(15-23)$ \\
\hline & & & $\begin{array}{l}\text { Nurse pulse } \\
\text { assessment of } \\
\text { frequent or } \\
\text { continuous } \\
\text { pulse } \\
\text { irregularity }\end{array}$ & 72 (59-82) & 94 (93-96) & $44(35-54)$ \\
\hline & & & $\begin{array}{l}\text { Nurse pulse } \\
\text { assessment } \\
\text { of continuous } \\
\text { pulse } \\
\text { irregularity }\end{array}$ & $54(4 I-66)$ & 98 (97-99) & $61(47-73)$ \\
\hline $\begin{array}{l}\text { Sudlow et al } \\
(1998)^{33}\end{array}$ & $\begin{array}{l}916 \text { patients aged } \\
\text { over } 65 \text { from nine } \\
\text { GP practices in } \\
\text { Northumberland. } \\
\text { Prevalence AF } 4.6 \% .^{*}\end{array}$ & Limb-lead ECG & $\begin{array}{l}\text { Nurse pulse } \\
\text { assessment } \\
\text { of any pulse } \\
\text { irregularity }\end{array}$ & $95(85-98) *$ & $70(67-73)^{*}$ & 13 \\
\hline $\begin{array}{l}\text { Somerville } \\
\text { et al }(2000)^{17}\end{array}$ & $\begin{array}{l}86 \text { patients selected } \\
\text { from a single GP } \\
\text { practice by inviting } \\
\text { all patients aged over } \\
65 \text { with recorded AF } \\
\text { and an equal number } \\
\text { of patients over } 65 \\
\text { without a diagnosis } \\
\text { of AF. Prevalence of } \\
\text { AF } 30 \% \text {. }\end{array}$ & $\begin{array}{l}\text { I2-lead ECG } \\
\text { interpreted by a } \\
\text { cardiologist }\end{array}$ & $\begin{array}{l}\text { Nurse pulse } \\
\text { assessment } \\
\text { of any pulse } \\
\text { irregularity }\end{array}$ & 97 & 79 & $68+$ \\
\hline $\begin{array}{l}\text { Hobbs et al } \\
(2005)^{13}\end{array}$ & $\begin{array}{l}2,578 \text { randomly } \\
\text { selected people aged } \\
\text { over } 65 \text { from } 25 \\
\text { GP practices taking } \\
\text { part in the SAFE } \\
\text { randomised control } \\
\text { trial between } 200 \text { I } \\
\text { and } 2003 \text {. Prevalence } \\
\text { of AF } 8.5 \% \text {. }\end{array}$ & $\begin{array}{l}\text { I2-lead ECG } \\
\text { interpreted by } \\
\text { two independent } \\
\text { cardiologists } \\
\text { with a third } \\
\text { cardiologist } \\
\text { arbitrating if } \\
\text { they were in } \\
\text { disagreement }\end{array}$ & $\begin{array}{l}\text { Nurse pulse } \\
\text { assessment } \\
\text { of any pulse } \\
\text { irregularity }\end{array}$ & 87 & 81 & 30 \\
\hline
\end{tabular}

privacy to perform. With regard to potential screening tests for $A F$, the simplest is pulse palpation. With a sensitivity of approximately $90 \%$, this is a reasonable screening test. The specificity is only moderate, with the result that in community settings, for every case of AF that is diagnosed, a further four people will have had an ECG that does not show AF. Thus, there is potential interest in screening tests with higher specificity, such as 'cut down' versions of I2-lead ECGs. Ignoring the issue of who reads the 'cut down' ECG, such tests are more specific than pulse palpation. Somerville et $\mathrm{al}^{17}$ for example found a specificity of $98 \%$ using a bipolar ECG. This would translate to a positive predictive value of $77 \%$ in a population with a $7 \%$ prevalence of $A F$ if the test sensitivity was $90 \%$ (i.e. three cases of AF would be diagnosed for every four I2-lead ECGs performed as a result of a positive bipolar ECG). However, in practice, who reads the ECGs needs to be taken into account as well. The study by Gregg et $\mathrm{a}^{22}$ found that interpretative software applied to a 'cut down' ECG only led to a 
K Harris, D Edwards, J Mant

TABLE 2 Studies of the accuracy of electrocardiograms with less than I2-leads in diagnosis of atrial fibrillation.

\begin{tabular}{|c|c|c|c|c|c|c|}
\hline Study & Population & $\begin{array}{l}\text { Reference } \\
\text { standard }\end{array}$ & $\begin{array}{l}\text { Method being } \\
\text { tested }\end{array}$ & \begin{tabular}{|l} 
Sensitivity \\
$\%(95 \%$ \\
confidence \\
interval where \\
known)
\end{tabular} & $\begin{array}{l}\text { Specificity } \\
\%(95 \% \\
\text { confidence } \\
\text { interval where } \\
\text { known) }\end{array}$ & $\begin{array}{l}\text { Positive } \\
\text { predictive } \\
\text { value ( } 95 \% \\
\text { confidence } \\
\text { interval where } \\
\text { known) }\end{array}$ \\
\hline \multirow[t]{2}{*}{$\begin{array}{l}\text { Somerville } \\
\text { et al }(2000)^{17}\end{array}$} & \multirow{2}{*}{$\begin{array}{l}86 \text { patients selected } \\
\text { from a single GP } \\
\text { practice by inviting all } \\
\text { patients aged } 65 \text { or } \\
\text { over with recorded } \\
\text { AF and an equal } \\
\text { number of patients } \\
\text { over } 65 \text { without a } \\
\text { diagnosis of AF. }\end{array}$} & \multirow[t]{2}{*}{$\begin{array}{l}\text { I 2-lead ECG } \\
\text { interpreted by a } \\
\text { cardiologist }\end{array}$} & $\begin{array}{l}\text { Bipolar ECG } \\
\text { interpreted by } \\
\text { a GP }\end{array}$ & $96(80-100)$ & $98(9 \mid-100)$ & 96 \\
\hline & & & $\begin{array}{l}\text { Bipolar ECG } \\
\text { interpreted by a } \\
\text { nurse }\end{array}$ & 94 & 92.5 & 84 \\
\hline \multirow[t]{2}{*}{$\begin{array}{l}\text { Gregg et al } \\
(2008)^{22}\end{array}$} & \multirow[t]{2}{*}{$\begin{array}{l}\text { I,785 ECGs randomly } \\
\text { selected from } \\
\text { teaching hospital } \\
\text { database. }\end{array}$} & \multirow[t]{2}{*}{$\begin{array}{l}\text { I2-lead ECG } \\
\text { interpreted by a } \\
\text { cardiologist }\end{array}$} & $\begin{array}{l}\text { I2-lead ECG } \\
\text { with leads } \\
\text { VI-V6 recon- } \\
\text { structed } \\
\text { from V2,V5 } \\
\text { interpreted by } \\
\text { inter-pretative } \\
\text { software }\end{array}$ & $84(76-90)$ & 99 (98-99) & 84 \\
\hline & & & $\begin{array}{l}\text { I2-lead ECG } \\
\text { with leads } \\
\text { VI-V6 recon- } \\
\text { structed } \\
\text { from VI,V4 } \\
\text { interpreted by } \\
\text { inter-pretative } \\
\text { software }\end{array}$ & $88(81-93)$ & 99 (98-99) & 85 \\
\hline $\begin{array}{l}\text { Doliwa et al } \\
(2008)^{16}\end{array}$ & $\begin{array}{l}100 \text { patients with } \\
\text { AF, atrial flutter or } \\
\text { sinus rhythm from } \\
\text { cardiology clinic.+ }\end{array}$ & $\begin{array}{l}\text { I2-lead ECG } \\
\text { interpreted by a } \\
\text { cardiologist }\end{array}$ & \begin{tabular}{|l|} 
Bipolar \\
'thumb' ECG \\
interpreted by a \\
cardiologist \\
\end{tabular} & 92 & 96 & 96 \\
\hline \multirow[t]{4}{*}{$\begin{array}{l}\text { Mant et al } \\
(2007)^{15}\end{array}$} & \multirow{4}{*}{$\begin{array}{l}2,595 \text { randomly } \\
\text { selected people } \\
\text { aged } 65 \text { or over } \\
\text { from } 25 \text { practices } \\
\text { taking part in the } \\
\text { SAFE randomised } \\
\text { controlled trial } \\
\text { between } 200 \text { I and } \\
2003 \text {. }\end{array}$} & \multirow{4}{*}{$\begin{array}{l}\text { I2-lead ECG } \\
\text { interpreted } \\
\text { by two } \\
\text { independent } \\
\text { cardiologists } \\
\text { with a third } \\
\text { cardiologist } \\
\text { arbitrating if } \\
\text { they were in } \\
\text { disagreement }\end{array}$} & \begin{tabular}{|l|} 
Single lead \\
thoracic \\
placement ECG \\
interpreted by \\
a GP \\
\end{tabular} & \begin{tabular}{|l|}
84.8 \\
$(78.7-91.0)$
\end{tabular} & \begin{tabular}{|l|}
86.4 \\
$(84.6-88.3)$
\end{tabular} & \\
\hline & & & $\begin{array}{l}\text { Single-lead } \\
\text { limb lead ECG } \\
\text { interpreted by } \\
\text { a GP } \\
\end{array}$ & \begin{tabular}{|l}
82.5 \\
$(74.8-88.7)$
\end{tabular} & $\begin{array}{l}88.5 \\
(86.9-90.2)\end{array}$ & \\
\hline & & & $\begin{array}{l}\text { Single-lead } \\
\text { thoracic } \\
\text { placement ECG } \\
\text { interpreted by a } \\
\text { nurse }\end{array}$ & \begin{tabular}{|l}
68.7 \\
$(60.1-76.4)$
\end{tabular} & $\begin{array}{l}82.8 \\
(80.7-84.8)\end{array}$ & \\
\hline & & & $\begin{array}{l}\text { Single-lead } \\
\text { limb lead ECG } \\
\text { interpreted by a } \\
\text { nurse }\end{array}$ & $\begin{array}{l}72.0 \\
(63.9-80.1)\end{array}$ & $\begin{array}{l}83.4 \\
(81.4-85.4)\end{array}$ & \\
\hline
\end{tabular}

sensitivity of $84-88 \%$, no better than pulse palpation. Studies evaluating newer technologies such as finger probes and modified blood pressure readings suggest that a sensitivity of greater than $90 \%$ could be achieved while maintaining reasonable specificity (84\%-92\%) (Table 3). In considering the potential role of these 
TABLE 3 Studies of the accuracy of alternative technologies in the diagnosis of atrial fibrillation.

\begin{tabular}{|c|c|c|c|c|c|c|}
\hline Study & Population & $\begin{array}{l}\text { Reference } \\
\text { standard }\end{array}$ & $\begin{array}{l}\text { Method being } \\
\text { tested }\end{array}$ & $\begin{array}{l}\text { Sensitivity } \\
\%(95 \% \\
\text { confidence } \\
\text { interval where } \\
\text { known) }\end{array}$ & $\begin{array}{l}\text { Specificity } \\
\%(95 \% \\
\text { confidence } \\
\text { interval where } \\
\text { known) }\end{array}$ & $\begin{array}{l}\text { Positive } \\
\text { predictive } \\
\text { value }(95 \% \\
\text { confidence } \\
\text { interval where } \\
\text { known) }\end{array}$ \\
\hline $\begin{array}{l}\text { Lewis et al } \\
(2010)^{18}\end{array}$ & $\begin{array}{l}594 \text { patients aged } \\
\text { over } 60 \text { years old } \\
\text { attending hospital } \\
\text { outpatient clinics } \\
\text { or inpatients at two } \\
\text { hospitals in South } \\
\text { Wales or New York. }\end{array}$ & $\begin{array}{l}\text { I2-lead ECG } \\
\text { interpreted } \\
\text { by a } \\
\text { cardiologist }\end{array}$ & $\begin{array}{l}\text { Finger probe with } \\
\text { threshold set after } \\
\text { reference standard } \\
\text { results available so } \\
\text { sensitivity } 100 \% \\
\text { with highest possible } \\
\text { coexisting specificity }\end{array}$ & 100 & 91.1 & \\
\hline \multirow[t]{3}{*}{$\begin{array}{l}\text { Wiesel } \\
\text { et al } \\
(2004)^{19}\end{array}$} & $\begin{array}{l}\text { I } 25 \text { cardiology } \\
\text { outpatients seen } \\
\text { between April and } \\
\text { August } 2002 .\end{array}$ & I2-lead ECG & $\begin{array}{l}\text { Modified blood } \\
\text { pressure monitor, } \\
\text { single reading } \\
\text { threshold set after } \\
\text { reference standard } \\
\text { results available so } \\
\text { sensitivity } 100 \% \\
\text { with highest possible } \\
\text { coexisting specificity }\end{array}$ & 100 & 92 & 90 \\
\hline & \multirow[t]{2}{*}{$\begin{array}{l}450 \text { cardiology } \\
\text { outpatients seen } \\
\text { between April and } \\
\text { August } 2002 .\end{array}$} & \multirow[t]{2}{*}{ 12-lead ECG } & $\begin{array}{l}\text { Modified blood } \\
\text { pressure monitor, } \\
\text { single reading }\end{array}$ & 100 & 84 & \\
\hline & & & $\begin{array}{l}\text { Modified blood } \\
\text { pressure monitor, } \\
\text { two readings where } \\
\text { final result irregular } \\
\text { if both readings are } \\
\text { irregular }\end{array}$ & 100 & 91 & \\
\hline \multirow[t]{2}{*}{$\begin{array}{l}\text { Wiesel } \\
\text { et al } \\
(2009)^{20}\end{array}$} & \multirow{2}{*}{$\begin{array}{l}405 \text { cardiology } \\
\text { outpatients in } \\
\text { two cardiology } \\
\text { departments in New } \\
\text { York. }\end{array}$} & \multirow{2}{*}{$\begin{array}{l}\text { I2-lead ECG } \\
\text { interpreted } \\
\text { by a } \\
\text { cardiologist }\end{array}$} & $\begin{array}{l}\text { Modified blood } \\
\text { pressure monitor, } \\
\text { single reading }\end{array}$ & $\begin{array}{l}95.3 \\
(92.8-97.6)\end{array}$ & $\begin{array}{l}86.4 \\
(84.3-97.6)\end{array}$ & 68 \\
\hline & & & $\begin{array}{l}\text { Modified blood } \\
\text { pressure monitor, } \\
\text { three readings where } \\
\text { final result irregular } \\
\text { if two out of three } \\
\text { readings are irregular }\end{array}$ & $\begin{array}{l}96.8 \\
(91-99)\end{array}$ & $\begin{array}{l}88.8 \\
(85-92)\end{array}$ & 72 \\
\hline \multirow[t]{2}{*}{$\begin{array}{l}\text { Stergiou et } \\
\text { al }(2009)^{21}\end{array}$} & \multirow{2}{*}{$\begin{array}{l}73 \text { patients aged over } \\
35 \text { with known AF } \\
\text { or other arrhythmias } \\
\text { and controls with } \\
\text { sinus rhythm from } \\
\text { an outpatient } \\
\text { hypertension clinic, } \\
\text { patients admitted to } \\
\text { a medical ward and } \\
\text { healthy volunteers. }\end{array}$} & \multirow{2}{*}{$\begin{array}{l}\text { I2-lead ECG } \\
\text { interpreted } \\
\text { by an } \\
\text { author and } \\
\text { verified by a } \\
\text { cardiologist }\end{array}$} & $\begin{array}{l}\text { Modified blood } \\
\text { pressure monitor, } \\
\text { single reading }\end{array}$ & $\begin{array}{l}93 \\
(74-99)\end{array}$ & $\begin{array}{l}89 \\
(76-96)\end{array}$ & 83 \\
\hline & & & $\begin{array}{l}\text { Modified blood } \\
\text { pressure monitor, } \\
\text { three readings where } \\
\text { final result irregular } \\
\text { if two out of three } \\
\text { readings are irregular }\end{array}$ & $\begin{array}{l}100 \\
(94-100)\end{array}$ & $\begin{array}{l}89 \\
(75-96)\end{array}$ & 84 \\
\hline
\end{tabular}

screening tools, the added costs of the screening needs to be set against the value of the detection of new cases of AF.A cost-effectiveness analysis comparing the use of a 12-lead ECG or 'cut down' ECGs found that the incremental cost per new case identified was similar. ${ }^{13}$ However, given that a I2-lead ECG would be indicated in someone who is in AF (a cost not taken into account in the cost-effectiveness analysis), this would raise the relative cost of a strategy that screened for $A F$ using simplified ECGs. Nevertheless, there would be a potential advantage in using a device that detected AF while performing another function (e.g. measuring blood 
K Harris, D Edwards, J Mant

TABLE 4 Studies of the detection rates of atrial fibrillation through screening.

\begin{tabular}{|c|c|c|c|c|c|}
\hline Study & Population & Allocation & $\begin{array}{l}\text { Systematic } \\
\text { screening } \\
\text { arm }\end{array}$ & $\begin{array}{l}\text { Opportunistic } \\
\text { screening } \\
\text { arm }\end{array}$ & Results \\
\hline $\begin{array}{l}\text { Fitzmaurice } \\
\text { et al }(2007)^{3}\end{array}$ & $\begin{array}{l}14,802 \text { patients } \\
\text { aged } 65 \text { or } \\
\text { over in } 50 \\
\text { GP practices } \\
\text { between } \\
\text { October } 2001 \\
\text { and February } \\
2003 .\end{array}$ & $\begin{array}{l}\text { GP practices } \\
\text { divided into } 25 \\
\text { intervention } \\
\text { and } 25 \text { control } \\
\text { practices. } \\
\text { Patients in the } \\
\text { intervention } \\
\text { practices were } \\
\text { randomly } \\
\text { allocated to } \\
\text { systematic or } \\
\text { opportunistic } \\
\text { screening }\end{array}$ & $\begin{array}{l}\text { Requested to } \\
\text { attend for ECG }\end{array}$ & $\begin{array}{l}\text { Notes flagged } \\
\text { to encourage } \\
\text { pulse check } \\
\text { during routine } \\
\text { consultation, with } \\
\text { ECG if found to be } \\
\text { irregular }\end{array}$ & $\begin{array}{l}\text { Detection rate of new cases of } \\
\text { AF of } 1.64 \% \text { with systematic } \\
\text { screening and } 1.62 \% \text { with } \\
\text { opportunistic screening } \\
\text { compared with } 1.04 \% \text { in } \\
\text { control practices. There was no } \\
\text { significant difference between } \\
\text { opportunistic and systematic } \\
\text { screening (difference } 0.02 \% \text {, } \\
-0.5 \% \text { to } 0.5 \% \text { ) }\end{array}$ \\
\hline $\begin{array}{l}\text { Morgan } \\
\text { et al } \\
(2001)^{14}\end{array}$ & $\begin{array}{l}\text { 3,00I patients } \\
\text { from four GP } \\
\text { practices. }\end{array}$ & $\begin{array}{l}\text { Patients randomly } \\
\text { allocated to } \\
\text { either systematic } \\
\text { or opportunistic } \\
\text { arm }\end{array}$ & $\begin{array}{l}\text { Requested to } \\
\text { attend for pulse } \\
\text { palpation by } \\
\text { nurse and ECG }\end{array}$ & $\begin{array}{l}\text { Flag inserted in } \\
\text { notes to request } \\
\text { that if pulse } \\
\text { checked as part of } \\
\text { normal practice } \\
\text { results recorded } \\
\text { and ECG if } \\
\text { suspicious of AF }\end{array}$ & $\begin{array}{l}\text { In the screening arm I,099 } \\
(73.3 \%) \text { patients had pulse } \\
\text { assessments and } 439 \text { ( } 29.2 \%) \\
\text { patients in the opportunistic } \\
\text { arm. In the screening arm } 67 \\
(4.5 \%) \text { patients had AF compared } \\
\text { to } 19(1.3 \%) \text { in the opportunistic } \\
\text { arm, with a difference in } \\
\text { percentage detected of } 3.2 \% \\
\text { (95\% confidence interval } 2.0- \\
4.4) \text {. In } 82 \% \text { of those detected in } \\
\text { the systematic screening arm AF } \\
\text { had previously been recorded } \\
\text { somewhere in their notes }\end{array}$ \\
\hline
\end{tabular}

pressure), since there will be minimal additional time costs. We did not identify any cost-effectiveness analyses of the use of such devices.

\section{Is it more effective to offer I2-lead ECGs in the whole population (or specific sub-groups) or only to those who screen positive for AF?}

Given that the reference standard test (12-lead ECG) is relatively straightforward to perform, an important question to address is whether screening should simply be carried out with this tool, without using any prior investigations. A related question is whether screening should be systematic (i.e. invite all people over a certain age for screening or in a particular sub-group) or opportunistic (i.e. screen for AF when a patient attends the general practice for another reason). These questions are linked as systematic screening is likely to be with a I2-lead ECG, and opportunistic screening with one of the approaches discussed above.

We found two studies that addressed this question (Table 4). The largest of these, the SAFE study, involved randomisation of 50 practices to either screening or no screening. ${ }^{3}$ Within the 25 practices randomised to screening, there was further randomisation at an individual patient level to opportunistic or systematic screening. In the opportunistic arm, a 'flag' (paper or electronic) was placed in the patient record to prompt a member of the primary care team to take the patient's pulse if they attended the practice. If the pulse was found to be irregular, then a I2-lead ECG was offered. In the systematic screening arm, patients were invited to attend the practice for a 12-lead ECG.The detection rate of new cases of AF was significantly higher in the screening practices as compared to the control practices, but there was no difference in the detection rate between systematic or opportunistic arms in the intervention practices. An economic analysis showed that opportunistic screening performed better than systematic screening (it was as effective but cost less), and was likely to be cost-effective in terms of cost per Quality Adjusted Life Year (QALY) gained as a result of reduced stroke incidence.

The second study randomised patients from four practices to systematic or opportunistic screening. ${ }^{14}$ In contrast to the SAFE study, ${ }^{3}$ this found systematic screening to be more effective than opportunistic screening. The take-up of opportunistic screening in this study was lower than in SAFE (29\% over a six-month period vs $69 \%$ over a year), and the take-up of systematic screening higher ( $73 \%$ vs $53 \%)$. The clinical implications of the second study are less clear, since the majority of 
TABLE 5 Studies of the accuracy of GPs, practice nurses and interpretive software in diagnosing atrial fibrillation on electrocardiogram.

\begin{tabular}{|c|c|c|c|c|c|c|}
\hline Study & Population & $\begin{array}{l}\text { Reference } \\
\text { standard }\end{array}$ & $\begin{array}{l}\text { Method being } \\
\text { tested }\end{array}$ & $\begin{array}{l}\text { Sensitivity } \\
\%(95 \% \\
\text { confidence } \\
\text { interval } \\
\text { where } \\
\text { known })\end{array}$ & $\begin{array}{l}\text { Specificity } \\
\%(95 \% \\
\text { confidence } \\
\text { interval } \\
\text { where } \\
\text { known) }\end{array}$ & $\begin{array}{l}\text { Positive } \\
\text { predictive } \\
\text { value }(95 \% \\
\text { confidence } \\
\text { interval } \\
\text { where } \\
\text { known) }\end{array}$ \\
\hline \multirow[t]{4}{*}{$\begin{array}{l}\text { Mant et al } \\
(2007)^{15}\end{array}$} & \multirow[t]{4}{*}{$\begin{array}{l}2,595 \text { randomly } \\
\text { selected people } \\
\text { aged } 65 \text { or over } \\
\text { from } 25 \text { practices } \\
\text { taking part in the } \\
\text { SAFE randomised } \\
\text { control trial } \\
\text { between } 200 \text { I and } \\
2003 \text {. }\end{array}$} & \multirow[t]{4}{*}{$\begin{array}{l}\text { Two independent } \\
\text { cardiologists } \\
\text { with a third } \\
\text { cardiologist } \\
\text { arbitrating if they } \\
\text { were in dis- } \\
\text { agreement }\end{array}$} & $\begin{array}{l}\text { ECG interpretation } \\
\text { by GPs }\end{array}$ & 80 (7I-87) & $92(90-93)$ & 40.9 \\
\hline & & & $\begin{array}{l}\text { ECG interpretation } \\
\text { by practice nurses }\end{array}$ & 77 (67-85) & 85 (83-87) & 27.2 \\
\hline & & & $\begin{array}{l}\text { ECG interpretation } \\
\text { by interpretative } \\
\text { software }\end{array}$ & 83 & 99 & 89.5 \\
\hline & & & $\begin{array}{l}\text { ECG interpretation } \\
\text { by GP and } \\
\text { interpretative } \\
\text { software }\end{array}$ & $\begin{array}{l}\text { Either } \\
\text { positive: } \\
92 \\
\text { Both positive: } \\
71\end{array}$ & $\begin{array}{l}91 \\
99.8\end{array}$ & $\begin{array}{l}42.9 \\
95.9\end{array}$ \\
\hline \multirow{2}{*}{$\begin{array}{l}\text { Somerville } \\
\text { et al } \\
(2000)^{17}\end{array}$} & \multirow{2}{*}{$\begin{array}{l}86 \text { patients selected } \\
\text { from a single GP } \\
\text { practice by inviting } \\
\text { all patients aged } \\
\text { over } 65 \text { with } \\
\text { recorded AF and } \\
\text { an equal number } \\
\text { of patients over } 65 \\
\text { without a diagnosis } \\
\text { of AF. }\end{array}$} & \multirow[t]{2}{*}{\begin{tabular}{|l|} 
Single \\
cardiologist
\end{tabular}} & $\begin{array}{l}\text { ECG interpretation } \\
\text { by GP }\end{array}$ & $100(87-100)$ & $98(91-100)$ & 96.0 \\
\hline & & & $\begin{array}{l}\text { ECG interpretation } \\
\text { by practice nurses }\end{array}$ & 97 & 88 & 79.0 \\
\hline $\begin{array}{l}\text { Anh et al } \\
(2006)^{24}\end{array}$ & $\begin{array}{l}\text { 2,298 consecutive } \\
\text { ECGs with } \\
\text { a software } \\
\text { interpretation of } \\
\text { AF from a hospital } \\
\text { database between } \\
\text { December } 200 \text { I and } \\
\text { June } 2002 \text {. }\end{array}$ & $\begin{array}{l}\text { Two independent } \\
\text { electro- } \\
\text { physiologists }\end{array}$ & $\begin{array}{l}\text { ECG interpretation } \\
\text { by interpretative } \\
\text { software }\end{array}$ & & & 81 \\
\hline $\begin{array}{l}\text { Poon et al } \\
(2005)^{35}\end{array}$ & $\begin{array}{l}4,297 \text { consecutive } \\
\text { inpatient or } \\
\text { outpatient ECGs } \\
\text { from a teaching } \\
\text { hospital. }\end{array}$ & $\begin{array}{l}\text { One of two } \\
\text { independent } \\
\text { cardiologists } \\
\text { with the second } \\
\text { checking any } \\
\text { ECGs where the } \\
\text { first cardiologist } \\
\text { disagreed } \\
\text { with the initial } \\
\text { computer inter- } \\
\text { pretation }\end{array}$ & $\begin{array}{l}\text { ECG interpretation } \\
\text { by interpretative } \\
\text { software }\end{array}$ & 90.8 & 98.9 & 84.7 \\
\hline
\end{tabular}


K Harris, D Edwards, J Mant

patients identified through systematic screening (82\%) already had a diagnosis of AF in their records, as compared to only $59 \%$ of the opportunistically screened group.

An integral part of determining screening strategy is to decide what population to include. Both these studies involved people aged 65 or over. SAFE also included a substudy of the potential impact of screening in 'high-risk' people over the age of 65 , i.e. those with a previous diagnosis of heart failure, hypertension, rheumatic heart disease, ischaemic heart disease, hyperthyroidism, or stroke/ TIA. ${ }^{13}$ A strategy of opportunistic screening of all people was both more effective and cost less than a strategy of systematic invitations to people in these sub-groups.

\section{How accurate are different healthcare professionals and interpretative software at diagnosing AF on ECG?}

A systematic review by Salerno et al in $2003^{23}$ of ECG interpretation accuracy studies found that both physicians and computer software frequently made errors compared to expert electrocardiographers, however there was also frequent disagreement in interpretation between experts.

Our search identified four studies which are summarised in Table 5. The largest study, by Mant et al ${ }^{15}$ investigated the ability of 42 general practitioners and 41 practice nurses to detect AF on ECGs generated during the SAFE study. Overall, primary care practitioners could not detect AF on an ECG with sufficient accuracy to guide therapy (GP sensitivity $80 \%$; specificity $92 \%$; practice nurse sensitivity $77 \%$; specificity $85 \%$ ). Interpretative software was found to be highly specific (99\%), but insufficiently sensitive (83\%). In practice, most ECG machines have interpretative software, but combining interpretative software with GP interpretation only improved the sensitivity to $92 \%$.

In contrast, Somerville et $\mathrm{al}^{17}$ found much higher sensitivity (100\%) and specificity $(98 \%)$ in their study of the performance of a single general practitioner. This is consistent with the findings of Mant et $\mathrm{al}^{15}$ in that some GPs in this study did perform as well as this (though the majority did not). This suggests that GPs can detect AF on ECGs accurately, with appropriate training. Indeed, it is of interest that the two cardiologists in the SAFE study, who independently read 2,592 ECGs, only disagreed on the presence of $A F$ in seven $(0.27 \%)$ cases.

The accuracy of interpretative software will of course depend upon the diagnostic algorithm that it uses. In the study by Mant et al ${ }^{15}$ all the ECGs were read using the same computer software. The two other studies that evaluated the accuracy of computer software for detecting AF found similar results to Mant et $\mathrm{al}^{15}$ even though different software was employed, suggesting that there may be some consistency between the algorithms used. Interpretative software is probably not yet good enough to be a diagnostic gold standard, but it is conceivable that improvements in the diagnostic algorithms in the future may make this possible.

These studies suggest that quality control of the interpretation of ECGs is an important aspect of diagnosis of $\mathrm{AF}$ in primary care. Two potential strategies to address this are to provide training to healthcare professionals who regularly read $\mathrm{ECGs}$ for $\mathrm{AF}$, or to have $\mathrm{ECG}$ centrally read. Of note with regard to the latter strategy,Anh et $\mathrm{a}^{24}$ found that in the case of incorrect computer diagnosis, cardiologists corrected the ECGs more often than other specialists when they had ordered the ECG (94\% vs 7I\%). However, when cardiologists had no patient contact and were presumably re-reading multiple ECGs, they corrected significantly less incorrect AF diagnoses than when they were the ordering physician (72 vs $94 \%$ ).

\section{How best can we diagnose paroxysmal atrial fibrillation?}

While a 12-lead ECG is the accepted reference standard for diagnosing permanent AF, it will only pick up some cases of paroxysmal AF, since the ECG recording is made at a fixed point in time which may or may not coincide with an episode of AF. Many patients with AF do not experience symptoms and there is not always a good correlation between symptoms and episodes of $\mathrm{AF}^{25} \mathrm{We}$ found no studies evaluating multiple-moment-in-time ECG monitoring in the asymptomatic general population. We found two studies where patients had been referred for suspected arrhythmias because of symptoms (usually palpitations, Table 6). Both studies compare the use of Holter monitoring (over 24-48 hours) with longer term monitoring (up to 90 days).

Reiffel et $\mathrm{al}^{26}$ found that the use of memory loop recorders for 30 days detected significantly more cases of AF than a 24-hour Holter monitor did, and that autotriggered memory loop recorders detected more AF than standard memory loop recorders. This study involved a retrospective review of records, so it is possible that there was indication bias (i.e. the clinician may have used memory loop recorders in patients where they thought there was a higher likelihood of detecting AF).

Kinlay et $\mathrm{a}^{27}$ performed a randomised crossover trial comparing the use of Holter monitoring for 48-hours against the use of a trans-telephonic post-event recorder, a handheld device that the patient activates when symptoms occur. The event monitors detected eight clinically important arrhythmias (including two cases of AF) in 43 patients, while Holter monitoring detected none. 
TABLE 6 Studies of the detection rates in patients with suspected atrial fibrillation using Holter monitors and event recorders.

\begin{tabular}{|c|c|c|c|}
\hline Study & Population & Method being tested & $\begin{array}{l}\text { Detection } \\
\text { rate }(\%)\end{array}$ \\
\hline \multirow[t]{3}{*}{$\begin{array}{l}\text { Reiffel et al } \\
(2005)^{26}\end{array}$} & \multirow{3}{*}{$\begin{array}{l}600 \text { patients retrospectively randomly } \\
\text { selected from a database of recordings from } \\
\text { patients referred for monitoring of known } \\
\text { or suspected arrhythmias during } 2003 \text {. }\end{array}$} & 24-hour Holter monitor & 4.5 \\
\hline & & 30-day memory loop recording & 12.5 \\
\hline & & $\begin{array}{l}\text { 30-day autotriggered memory loop } \\
\text { recording }\end{array}$ & 24.3 \\
\hline \multirow{2}{*}{$\begin{array}{l}\text { Kinlay et al } \\
(1996)^{27}\end{array}$} & \multirow{2}{*}{$\begin{array}{l}43 \text { patients referred to an Australian } \\
\text { hospital for first time Holter monitoring for } \\
\text { palpitations. }\end{array}$} & 48-hour Holter monitor & 0 \\
\hline & & $\begin{array}{l}\text { Three-month trans-telephonic event } \\
\text { monitor }\end{array}$ & 4.7 \\
\hline
\end{tabular}

\section{What is the impact of the use of different ECG monitoring strategies on AF detection rates post- stroke?}

In contrast to the relative lack of studies on the detection of paroxysmal AF in the general population, we found several studies looking at detection rates of $A F$ following stroke (Table 7). Performing an ECG on admission is standard practice but will miss some cases of PAF. The detection rates in these studies vary widely from $0 \%$ to $45 \%$. This variation reflects differences in study population, method of ECG monitoring used (e.g. serial ECGs, Holter monitors, continuous ECG monitoring, cardiac event recorders), minimum duration of $A F$ required for diagnosis and length of time that the ECG monitoring was carried out. It is therefore difficult to draw any firm conclusions, other than that the longer the monitoring is carried out, the more cases of AF are detected (Figure I). Newer technologies are emerging in this rapidly developing field. For example, implantable cardiac event monitors can be used which potentially allow for long-term detection of $\mathrm{AF}^{28}$ Before firm recommendations can be made on the optimal strategy for detecting
AF post-stroke, stronger evidence is needed on the utility of detection of these additional cases of AF. While there is evidence that paroxysmal AF carries a similar prognosis to permanent $\mathrm{AF}^{29,12}$ data are required to confirm that $\mathrm{AF}$ detected using these novel approaches carries the same risk. Recently, Healey et al found that subclinical atrial tachyarrhythmias lasting at least six minutes detected by implanted devices were associated with an increased risk of ischaemic stroke or systemic embolism (hazard ratio: $2.5,95 \% \mathrm{Cl}$ I.3-4.9 $)^{30}$, but this is lower than that associated with clinical AF. It should be noted that several of the studies listed in Table 7 defined AF using time periods considerably shorter than six minutes. Comparative evidence of the cost-effectiveness of the different monitoring strategies is required, ideally from randomised controlled trials.

\section{TOWARDS A STRATEGY TO DETECT AF}

It is likely to be cost-effective to opportunistically screen patients aged over 65 annually for AF. This means opportunistically checking the patient's pulse when they

TABLE 7 Studies of the detection rates of atrial fibrillation in acute stroke/transient ischaemic attack (TIA) patients.

\begin{tabular}{|l|l|l|l|l|l|}
\hline Study & Population & Method being tested & $\begin{array}{l}\text { Time to } \\
\text { starting } \\
\text { measurement }\end{array}$ & $\begin{array}{l}\text { Definition of } \\
\text { paroxysmal } \\
\text { atrial } \\
\text { fibrillation }\end{array}$ & $\begin{array}{l}\text { Detection } \\
\text { rate (\%) }\end{array}$ \\
\hline $\begin{array}{l}\text { Gunalp et al } \\
(2006)^{36}\end{array}$ & $\begin{array}{l}\text { 26 patients presenting with } \\
\text { acute stroke and an ischaemic } \\
\text { lesion }>3 \mathrm{~cm} \text {, excluding those } \\
\text { with a rhythm disturbance } \\
\text { on admission ECG and those } \\
\text { taking certain medications. }\end{array}$ & 24-hour Holter ECG & & & $45(\mathrm{n}=\mathrm{II})$ \\
\hline $\begin{array}{l}\text { Tagawa et al al } \\
(2007)^{37}\end{array}$ & $\begin{array}{l}308 \text { consecutive patients } \\
\text { presenting with acute ischaemic } \\
\text { stroke at a Japanese hospital } \\
\text { between November 200I and } \\
\text { May 2004. }\end{array}$ & 24-hour Holter ECG & $\begin{array}{l}\text { Mean 5.8 days } \\
\text { (range 2-18 days) }\end{array}$ & & 31.5 \\
\hline
\end{tabular}


K Harris, D Edwards, J Mant

TABLE 7 (continued) Studies of the detection rates of atrial fibrillation in acute stroke/transient ischeamic attack (TIA) patients.

\begin{tabular}{|c|c|c|c|c|c|}
\hline Study & Population & Method being tested & $\begin{array}{l}\text { Time to } \\
\text { starting } \\
\text { measurement }\end{array}$ & $\begin{array}{l}\text { Definition of } \\
\text { paroxysmal } \\
\text { atrial } \\
\text { fibrillation }\end{array}$ & $\begin{array}{l}\text { Detection } \\
\text { rate (\%) }\end{array}$ \\
\hline $\begin{array}{l}\text { Douen et } \\
\mathrm{al}^{38}(2008)\end{array}$ & \begin{tabular}{|l|} 
Retrospective study of 126 \\
patients admitted to a stroke \\
unit, excluding those with intra- \\
cerebal haemorrhage during an \\
8.5 month period in 2005.
\end{tabular} & $\begin{array}{l}\text { Holter ECG, duration } \\
\text { not specified }\end{array}$ & & & $9.5 *$ \\
\hline $\begin{array}{l}\text { Yu et al }{ }^{39} \\
(2009)\end{array}$ & $\begin{array}{l}\text { Retrospective study of } 96 \\
\text { patients admitted to a teaching } \\
\text { hospital with ischaemic stroke, } \\
\text { excluding those with known } \\
\text { AF from January } 2003 \text { to } \\
\text { December } 2005 .\end{array}$ & 24-hour Holter monitor & During admission & & 9.4 \\
\hline \multirow[t]{2}{*}{$\begin{array}{l}\text { Alhadramy } \\
\text { et } \mathrm{a}^{40} \\
(2010)\end{array}$} & \multirow{2}{*}{$\begin{array}{l}\text { Retrospective study of } 413 \\
\text { patients diagnosed with } \\
\text { stroke or TIA, excluding } \\
\text { those with history of AF, } \\
\text { at a university stroke clinic } \\
\text { between September } 2005 \text { and } \\
\text { September } 2006 \text {. }\end{array}$} & \multirow[t]{2}{*}{$\begin{array}{l}\text { Holter ECG, average } \\
22.6 \text { hours }\end{array}$} & \multirow[t]{2}{*}{$\begin{array}{l}\text { From a few days } \\
\text { to three months }\end{array}$} & Any duration & 9.2 \\
\hline & & & & $>30$ seconds & 2.5 \\
\hline $\begin{array}{l}\text { Lazzaro et } \\
\mathrm{al}^{41}(2010)\end{array}$ & $\begin{array}{l}\text { I } 33 \text { patients admitted to a } \\
\text { teaching hospital with ischaemic } \\
\text { stroke or TIA between June } \\
2007 \text { and December } 2008 \text {, } \\
\text { excluding those with a history } \\
\text { of AF or AF on admission ECG. }\end{array}$ & $\begin{array}{l}\text { Holter ECG, mean } \\
\text { duration } 29.8 \text { hours }\end{array}$ & During admission & $>30$ seconds & 6.0 \\
\hline $\begin{array}{l}\text { Barthelemy } \\
\text { et } \mathrm{al}^{42} \\
(2003)\end{array}$ & $\begin{array}{l}55 \text { patients admitted to a } \\
\text { university hospital with stroke } \\
\text { or TIA, excluding those with } \\
\text { AF detected on two admission } \\
\text { ECGs between January and } \\
\text { December I } 998 \text {. }\end{array}$ & 24-hour Holter ECG & During admission & $>30$ seconds & 5.5 \\
\hline $\begin{array}{l}\text { Jabaudon et } \\
\mathrm{al}^{43}(2004)\end{array}$ & $\begin{array}{l}\text { I39 patients admitted with } \\
\text { suspicion of acute stroke or } \\
\text { TIA to a university hospital, } \\
\text { excluding those with } \\
\text { haemorrhagic stroke or recent } \\
\text { history of AF or AF detected on } \\
\text { initial ECG, between February } \\
\text { and December } 2002 \text {. }\end{array}$ & 24-hour Holter ECG & $\begin{array}{l}\text { Median } 8 \text { days } \\
\text { (range I-29) }\end{array}$ & & $\begin{array}{l}5.0 \\
\text { (confidence } \\
\text { interval } \\
2.3-10.2 \text { ) }\end{array}$ \\
\hline $\begin{array}{l}\text { Koudstaal } \\
\text { et } \mathrm{al}^{44} \\
(1986)\end{array}$ & $\begin{array}{l}\text { Retrospective study of } 100 \\
\text { patients admitted to a teaching } \\
\text { hospital with a TIA who had a } \\
\text { Holter monitor. }\end{array}$ & 24-hour Holter ECG & $\begin{array}{l}\text { Mean I } 5.2 \text { days } \\
\text { from onset of } \\
\text { symptoms }\end{array}$ & & 5 \\
\hline $\begin{array}{l}\text { Schaer et } \\
\mathrm{al}^{45}(2004)\end{array}$ & $\begin{array}{l}\text { Retrospective study of } 425 \\
\text { hospitalised patients admitted } \\
\text { with cerebral ischaemic } \\
\text { event who had a Holter ECG } \\
\text { between January } 2000 \text { and } \\
\text { December } 2002 .\end{array}$ & 24-hour Holter ECG & & $>30$ seconds & 4.9 \\
\hline
\end{tabular}


TABLE 7 (continued) Studies of the detection rates of atrial fibrillation in acute stroke/transient ischeamic attack (TIA) patients.

\begin{tabular}{|c|c|c|c|c|c|}
\hline Study & Population & Method being tested & \begin{tabular}{|l|} 
Time to \\
starting \\
measurement
\end{tabular} & $\begin{array}{l}\text { Definition of } \\
\text { paroxysmal } \\
\text { atrial } \\
\text { fibrillation }\end{array}$ & $\begin{array}{l}\text { Detection } \\
\text { rate }(\%)\end{array}$ \\
\hline \multirow[t]{4}{*}{$\begin{array}{l}\text { Stahrenberg } \\
\text { et } \mathrm{al}^{46} \\
(2010)\end{array}$} & \multirow{4}{*}{$\begin{array}{l}224 \text { patients presenting with } \\
\text { suspected stroke/TIA to } \\
\text { an Emergency Department } \\
\text { between March } 2009 \text { and } \\
\text { February } 2010 \text { excluding those } \\
\text { with AF on baseline ECG. }\end{array}$} & $\begin{array}{l}\text { 24-hour Holter ECG } \\
\text { (average of seven 24- } \\
\text { hour records) }\end{array}$ & $\begin{array}{l}\text { Median } 5.5 \text { hours } \\
\text { after admission }\end{array}$ & $>30$ seconds & 4.8 \\
\hline & & $\begin{array}{l}\text { 48-hour Holter ECG } \\
\text { (average of six 48-hour } \\
\text { records) }\end{array}$ & $\begin{array}{l}\text { Median } 5.5 \text { hours } \\
\text { after admission }\end{array}$ & $>30$ seconds & 6.4 \\
\hline & & \multirow[t]{2}{*}{ Seven day Holter ECG } & \multirow{2}{*}{$\begin{array}{l}\text { Median } 5.5 \text { hours } \\
\text { after admission }\end{array}$} & $>30$ seconds & 12.5 \\
\hline & & & & $\begin{array}{l}>10 \text { beats in } \\
\text { a row }\end{array}$ & 43.8 \\
\hline $\begin{array}{l}\text { Rem et } \mathrm{al}^{47} \\
(1985)\end{array}$ & $\begin{array}{l}\text { I5I patients with acute stroke } \\
\text { or TIA admitted to a stroke } \\
\text { unit, excluding those with } \\
\text { a history of arrhythmia or } \\
\text { detected on admission ECG } \\
\text { or } 48 \text {-hour cardiac monitoring, } \\
\text { between January and December } \\
\text { 1983. }\end{array}$ & $\begin{array}{l}\text { 24-48-hour Holter } \\
\text { ECG }\end{array}$ & & & 3.9 \\
\hline $\begin{array}{l}\text { Hornig } \\
\text { et } \mathrm{a}^{48} \\
(1996)\end{array}$ & $\begin{array}{l}26 \mathrm{I} \text { patients with acute focal } \\
\text { brain ischaemia, excluding those } \\
\text { in } A F \text { on admission ECG. }\end{array}$ & 24-hour Holter ECG & & & 3.8 \\
\hline $\begin{array}{l}\text { Shafqat } \\
\text { et } \mathrm{al}^{49} \\
(2003)\end{array}$ & $\begin{array}{l}\text { Retrospective study of } 194 \\
\text { patients admitted to a teaching } \\
\text { hospital with acute ischaemic } \\
\text { stroke, excluding those with AF } \\
\text { on admission ECG. }\end{array}$ & 24-hour Holter ECG & & & 2.6 \\
\hline $\begin{array}{l}\text { Rizos et } \mathrm{al}^{50} \\
(2010)\end{array}$ & $\begin{array}{l}\text { I } 20 \text { patients aged over } 60 \\
\text { presenting with acute stroke } \\
\text { or TIA at a university hospital, } \\
\text { excluding those with history of } \\
\text { AF or AF shown on admission } \\
\text { ECG or continuous ECG in } \\
\text { first } 24 \text { hours, between July } \\
2008 \text { and March } 2009 .\end{array}$ & 24-hour Holter ECG & Median 49 hours & $>30$ seconds & 2.5 \\
\hline \multirow{3}{*}{$\begin{array}{l}\text { Schuchert } \\
\text { et } \mathrm{al}^{51} \\
(1999)\end{array}$} & \multirow{3}{*}{$\begin{array}{l}82 \text { patients with acute } \\
\text { ischaemic stroke, excluding } \\
\text { those with a history of AF or } \\
\text { AF on resting ECG. }\end{array}$} & 24-hour Holter ECG & 2-3 weeks & $>60$ seconds & 1.2 \\
\hline & & 48-hour Holter ECG & & $>60$ seconds & 3.7 \\
\hline & & 72-hour Holter ECG & & $>60$ seconds & 6.1 \\
\hline $\begin{array}{l}\text { Gunalp } \\
\text { et } \mathrm{al}^{36} \\
(2006)\end{array}$ & $\begin{array}{l}26 \text { patients presenting with } \\
\text { acute stroke and an ischaemic } \\
\text { lesion }>3 \mathrm{~cm} \text {, excluding those } \\
\text { with a rhythm disturbance } \\
\text { on admission ECG and those } \\
\text { taking certain medications. }\end{array}$ & $\begin{array}{l}\text { Three ECGs taken at six } \\
\text { hourly intervals }\end{array}$ & $\begin{array}{l}\text { Six hours after } \\
\text { admission ECG }\end{array}$ & & II (n=3) \\
\hline $\begin{array}{l}\text { Kamel } \\
\text { et al } \\
(2009)\end{array}$ & $\begin{array}{l}\text { Retrospective study of } 2,504 \\
\text { patients with acute stroke } \\
\text { in the placebo arms of four } \\
\text { randomised control trials, } \\
\text { excluding those with a history } \\
\text { of AF or AF on their admission } \\
\text { ECG. }\end{array}$ & $\begin{array}{l}\text { Serial ECGs up to } 90 \\
\text { days }\end{array}$ & $\begin{array}{l}\text { All patients } \\
\text { enrolled within } \\
12 \text { hours of onset } \\
\text { of symptoms, } \\
\text { ECGs started on } \\
\text { admission }\end{array}$ & & 6.9 \\
\hline
\end{tabular}


K Harris, D Edwards, J Mant

TABLE 7 (continued) Studies of the detection rates of atrial fibrillation in acute stroke/transient ischeamic attack (TIA) patients.

\begin{tabular}{|c|c|c|c|c|c|}
\hline Study & Population & Method being tested & \begin{tabular}{|l|} 
Time to \\
starting \\
measurement
\end{tabular} & \begin{tabular}{|l|} 
Definition of \\
paroxysmal \\
atrial \\
fibrillation \\
\end{tabular} & $\begin{array}{l}\text { Detection } \\
\text { rate (\%) }\end{array}$ \\
\hline $\begin{array}{l}\text { Douen } \\
\text { et } \mathrm{a}^{38} \\
(2008)\end{array}$ & $\begin{array}{l}\text { Retrospective review of I } 26 \\
\text { patients admitted to a stroke } \\
\text { unit, excluding those with } \\
\text { intra-cerebal haemorrhage and } \\
\text { those with a history of AF or } \\
\text { AF detected on admission ECG } \\
\text { during an } 8.5 \text { month period in } \\
2005 \text {. }\end{array}$ & $\begin{array}{l}\text { Serial ECGs in first } 72 \\
\text { hours after admission }\end{array}$ & & & $6.3^{*}$ \\
\hline $\begin{array}{l}\text { Gaillard } \\
\text { et al } \\
(2010)\end{array}$ & $\begin{array}{l}\text { Retrospective study of } 98 \\
\text { patients with acute stroke or } \\
\text { TIA admitted to a stroke unit } \\
\text { between December } 2003 \text { and } \\
\text { January } 2006 \text { with a negative } \\
\text { Holter ECG who had a trans- } \\
\text { telephonic ECG. }\end{array}$ & $\begin{array}{l}\text { Trans-telephonic ECG } \\
\text { monitoring (patients } \\
\text { self-recorded at least } \\
\text { one ECG each day } \\
\text { for one month and } \\
\text { transmitted the results } \\
\text { by telephone to a } \\
\text { cardiology centre) }\end{array}$ & $\begin{array}{l}\text { Within six months } \\
\text { of presentation }\end{array}$ & $>32$ seconds & 9.2 \\
\hline $\begin{array}{l}\text { Rizos et al }{ }^{50} \\
(2010)\end{array}$ & $\begin{array}{l}\text { I } 36 \text { patients aged over } 60 \\
\text { presenting with acute stroke } \\
\text { or TIA at a university hospital, } \\
\text { excluding those with a } \\
\text { history of AF or AF shown on } \\
\text { admission ECG between July } \\
2008 \text { and March } 2009 \text {. }\end{array}$ & $\begin{array}{l}\text { Continuous bedside } \\
\text { ECG monitoring, } \\
\text { median duration } 97 \\
\text { hours (interquartile } \\
\text { range [IQR] } 82-144 \text { ) } \\
\text { with confirmation I2- } \\
\text { lead ECG of suspected } \\
\text { episodes }\end{array}$ & $\begin{array}{l}\text { Immediately on } \\
\text { admission to ward }\end{array}$ & & 21 \\
\hline $\begin{array}{l}\text { Rem et al }{ }^{47} \\
(1985)\end{array}$ & $\begin{array}{l}\text { I60 patients with acute stroke } \\
\text { or TIA admitted to a stroke } \\
\text { unit, excluding those with a } \\
\text { history of arrhythmia or one } \\
\text { detected on admission ECG } \\
\text { between January and December } \\
\text { I983. }\end{array}$ & $\begin{array}{l}\text { 48-hour bedside cardiac } \\
\text { monitoring }\end{array}$ & & & 2.5 \\
\hline $\begin{array}{l}\text { Lazzaro } \\
\text { et } \mathrm{al}^{41} \\
(2010)\end{array}$ & $\begin{array}{l}\text { I } 33 \text { patients admitted to a } \\
\text { teaching hospital with ischaemic } \\
\text { stroke or TIA between June } \\
2007 \text { and December } 2008 \text {, } \\
\text { excluding those with a history } \\
\text { of AF or AF on admission ECG. }\end{array}$ & $\begin{array}{l}\text { Continuous bedside } \\
\text { cardiac telemetry, mean } \\
\text { duration } 73.6 \text { hours } \\
\text { with nurse review } \\
\text { every eight hours or if } \\
\text { abnormal rate/rhythm } \\
\text { detected by device }\end{array}$ & During admission & $>30$ seconds & 0 \\
\hline $\begin{array}{l}\text { Barthelemy } \\
\text { et al }{ }^{42} \\
(2003)\end{array}$ & $\begin{array}{l}52 \text { patients admitted to a } \\
\text { university hospital with stroke } \\
\text { or TIA, excluding those with } \\
\text { AF detected on two admission } \\
\text { ECGs or on Holter ECG } \\
\text { between January and December } \\
\text { I998. }\end{array}$ & $\begin{array}{l}\text { Automatic self-analysing } \\
\text { cardiac event recorders, } \\
\text { mean duration } 70.1 \\
\text { hours }\end{array}$ & Mean $10+/-2$ days & $\begin{array}{l}>1=30 \\
\text { seconds }\end{array}$ & 7.7 \\
\hline \multirow[t]{2}{*}{$\begin{array}{l}\text { Tayal et al }{ }^{54} \\
(2008)\end{array}$} & \multirow{2}{*}{$\begin{array}{l}\text { Retrospective study of } 56 \\
\text { patients admitted to hospital } \\
\text { with TIA/stroke without clear } \\
\text { cause between January } 2006 \\
\text { and May 2007, excluding those } \\
\text { with a history of AF or AF on } \\
\text { admission ECG or 24-hour } \\
\text { Holter ECG. }\end{array}$} & \multirow{2}{*}{$\begin{array}{l}2 \text { I day mobile cardiac } \\
\text { outpatient telemetry } \\
\text { monitoring (auto- } \\
\text { triggered device which } \\
\text { transmits possible AF } \\
\text { events to a physician for } \\
\text { review) }\end{array}$} & \multirow[t]{2}{*}{$\begin{array}{l}\text { Median } 20 \text { days } \\
\text { from onset } \\
\text { symptoms }\end{array}$} & $>30$ seconds & 5.3 \\
\hline & & & & Any duration & 23 \\
\hline
\end{tabular}


TABLE 7 (continued) Studies of the detection rates of atrial fibrillation in acute stroke/transient ischaemic attack (TIA) patients.

\begin{tabular}{|c|c|c|c|c|c|}
\hline Study & Population & Method being tested & $\begin{array}{l}\text { Time to } \\
\text { starting } \\
\text { measurement }\end{array}$ & $\begin{array}{l}\text { Definition of } \\
\text { paroxysmal } \\
\text { atrial } \\
\text { fibrillation }\end{array}$ & $\begin{array}{l}\text { Detection } \\
\text { rate (\%) }\end{array}$ \\
\hline $\begin{array}{l}\text { Elijovich } \\
\text { et } \mathrm{al}^{55} \\
(2009)\end{array}$ & $\begin{array}{l}\text { Retrospective study of } 21 \\
\text { patients with stroke or TIA } \\
\text { without clear cause admitted } \\
\text { to a university stroke centre or } \\
\text { seen in outpatient stroke clinic } \\
\text { from June } 2006 \text { to March } 2007 \\
\text { who were referred for } 30 \text {-day } \\
\text { cardiac event monitor. }\end{array}$ & $\begin{array}{l}\text { 30-day ambulatory } \\
\text { cardiac event monitor } \\
\text { (auto-triggered and } \\
\text { patient-triggered } \\
\text { recordings were sent } \\
\text { to a cardiologist for } \\
\text { review) }\end{array}$ & & $>30$ seconds & $20(n=4)$ \\
\hline $\begin{array}{l}\text { Jabaudon } \\
\text { et } \mathrm{al}^{43}(2004\end{array}$ & $\begin{array}{l}88 \text { patients admitted with } \\
\text { suspicion of acute stroke or } \\
\text { TIA to a university hospital, } \\
\text { excluding those with } \\
\text { haemorrhagic stroke or a } \\
\text { recent history of AF or AF } \\
\text { detected on initial ECG or } \\
24 \text {-hour Holter monitoring } \\
\text { and those that refused the } \\
\text { test between February and } \\
\text { December } 2002 \text {. }\end{array}$ & $\begin{array}{l}\text { Seven day event loop } \\
\text { recording device } \\
\text { with auto-triggered } \\
\text { and patient-triggered } \\
\text { recording }\end{array}$ & Median 55 days & & \begin{tabular}{|l|}
5.7 \\
(confidence \\
interval 2.I \\
to 12.9)
\end{tabular} \\
\hline $\begin{array}{l}\text { Dion et } a^{56} \\
(2010)\end{array}$ & $\begin{array}{l}24 \text { patients diagnosed with } \\
\text { cryptogenic stroke or TIA } \\
\text { who had normal I2-lead ECG, } \\
\text { 24-hour Holter monitoring and } \\
\text { echocardiography. }\end{array}$ & $\begin{array}{l}\text { Implantable loop } \\
\text { recorder, mean duration } \\
\text { I } 4.5 \text { months }\end{array}$ & $\begin{array}{l}\text { Within four } \\
\text { months of } \\
\text { diagnosis }\end{array}$ & Any duration & $4.2(n=I)$ \\
\hline
\end{tabular}

attend the GP surgery for an unrelated reason (e.g. an appointment with the practice nurse for a flu jab) and arranging an ECG if the pulse is irregular. This strategy would have the potential to detect AF in the estimated $97 \%$ of patients aged over 65 who see a member of the general practice team at least once annually. ${ }^{33}$ Given that the prevalence of $\mathrm{AF}$ is over $8 \%$ in this age group ${ }^{3}$ and average consultation rates are over seven consultations per personyear $^{34}$ it would also be good practice to consider checking the pulse for irregularity whenever the opportunity arises.

\section{CONCLUSION}

Existing guidelines are summarised in Table 8.The following conclusions may be drawn from this review of the evidence base for the detection of AF.

I. In the general population (Figure 2):

- Opportunistic screening is more cost-effective than systematic screening.

Considerations of whom to screen opportunistically will depend on an understanding of the epidemiology of AF. Prevalence of AF and the risk of stroke rise significantly with age, so both potential yield and potential benefit from treatment increases in older age groups. The evidence base for screening is largely in people aged 65 and over.

- A number of methods may be employed to screen opportunistically. The cheapest of these is pulse palpation.The cost-effectiveness of newer technologies such as modified blood pressure monitors need to be assessed.

- 12-lead ECG remains the standard investigation, but the accuracy of this investigation falls if it is read by someone without adequate training.

2. In the symptomatic population (e.g. post-stroke or with symptoms such as palpitations):

- If a 12-lead ECG fails to show AF, then a number of different technologies are available that allow for longer term ECG monitoring. The relative costeffectiveness of these technologies needs to be evaluated before a firm recommendation can be made in favour of any specific approach. 
K Harris, D Edwards, J Mant

\section{FIGURE I Detection rate of atrial fibrillation versus time post-stroke}

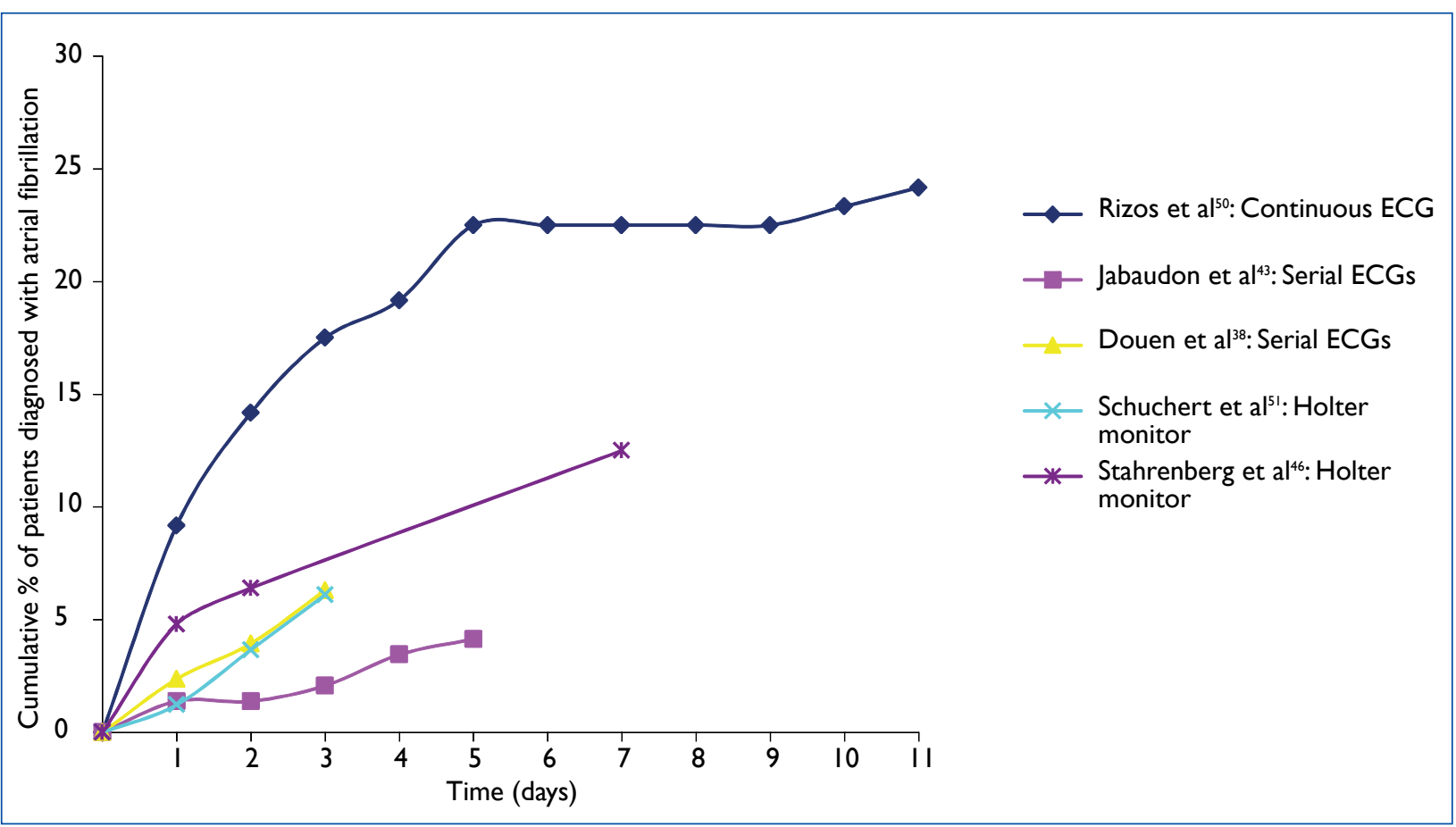

ECG: Electrocardiogram

TABLE 8 Summary of current guidance.

\begin{tabular}{|c|c|}
\hline Guidelines & Guidance \\
\hline $\begin{array}{l}\text { ACC/AHA/ESC Guidelines for the management of patients } \\
\text { with atrial fibrillation }(2006)^{57}\end{array}$ & $\begin{array}{l}\text { The diagnosis of AF requires ECG documentation by at least } \\
\text { a single-lead ECG recording during the dysrrhythmia, which } \\
\text { may be facilitated by a review of emergency department } \\
\text { records, Holter monitoring, or trans-telephonic or telemetric } \\
\text { recordings. A portable ECG recording tool may help establish } \\
\text { the diagnosis in cases of paroxysmal AF and provide a } \\
\text { permanent ECG record of the dysrrhythmia. If episodes } \\
\text { are frequent, then a } 24 \text {-hour Holter monitor can be used. If } \\
\text { episodes are infrequent, then an event recorder, which allows } \\
\text { the patient to transmit the ECG to a recording facility when } \\
\text { the arrhythmia occurs, may be more useful. }\end{array}$ \\
\hline $\begin{array}{l}\text { NICE Atrial fibrillation guidelines: national clinical guideline for } \\
\text { management in primary and secondary care }(2006)^{2}\end{array}$ & $\begin{array}{l}\text { In patients presenting with any of the following: } \\
\text { breathlessness/dyspnoea, palpitations, syncope/dizziness, chest } \\
\text { discomfort, stroke/transient ischaemic attack (TIA): } \\
\text { - Manual pulse palpation should be performed to assess } \\
\text { for the presence of an irregular pulse that may indicate } \\
\text { underlying AF. } \\
\text { An ECG should be performed in all patients, whether } \\
\text { symptomatic or not, in whom AF is suspected because } \\
\text { an irregular pulse has been detected. } \\
\text { In patients with suspected paroxysmal AF undetected by } \\
\text { standard ECG recording: } \\
\text { A } 24 \text {-hour ambulatory ECG monitor should be used } \\
\text { in those with suspected asymptomatic episodes or } \\
\text { symptomatic episodes less than } 24 \text { hours apart. } \\
\text { An event recorded ECG should be used in those with } \\
\text { symptomatic episodes more than } 24 \text { hours apart. }\end{array}$ \\
\hline
\end{tabular}




\begin{tabular}{|c|c|}
\hline Guidelines & Guidance \\
\hline SIGN Cardiac arrhythmias in coronary heart disease $(2007)^{58}$ & No specific guidance on how to detect AF. \\
\hline $\begin{array}{l}\text { SIGN Management of patients with stroke or TIA: assessment, } \\
\text { investigation, immediate management and secondary } \\
\text { prevention }(2008)^{59}\end{array}$ & $\begin{array}{l}\text { Guidelines recommend frequent ECG monitoring in the } \\
\text { acute phase post-stroke, but does not mention anything } \\
\text { specific about detecting AF. }\end{array}$ \\
\hline $\begin{array}{l}\text { European Stroke Organisation: Guidelines for management of } \\
\text { ischaemic stroke and transient ischaemic attack }(2008)^{60}\end{array}$ & $\begin{array}{l}\text { It is recommended that all acute stroke and TIA patients } \\
\text { should have a I2-lead ECG. In addition, continuous ECG } \\
\text { recording is recommended for ischaemic stroke and TIA } \\
\text { patients. } \\
\text { It is recommended that for stroke and TIA patients seen after } \\
\text { the acute phase, } 24 \text {-hour Holter ECG monitoring should be } \\
\text { performed when arrhythmias are suspected and no other } \\
\text { causes of stroke are found. }\end{array}$ \\
\hline $\begin{array}{l}\text { NICE stroke guidance: National clinical guideline for diagnosis } \\
\text { and initial management of acute stroke and transient } \\
\text { ischaemic attack (TIA) }(2008)^{61}\end{array}$ & No specific guidance on how to detect AF. \\
\hline $\begin{array}{l}\text { ESC Clinical practice guidelines: atrial fibrillation (management } \\
\text { of) }(2010)^{\prime \prime}\end{array}$ & $\begin{array}{l}\text { The diagnosis of AF requires documentation by ECG. } \\
\text { - In patients with suspected AF, an attempt to record an } \\
\text { ECG should be made when symptoms suggestive of AF } \\
\text { occur. } \\
\text { - In patients with suspected symptomatic AF, additional } \\
\text { ECG monitoring should be considered in order to } \\
\text { document the arrhythmia. } \\
\text { - Additional ECG monitoring should be considered } \\
\text { for detection of 'silent' AF in patients who may have } \\
\text { sustained an AF-related complication. }\end{array}$ \\
\hline $\begin{array}{l}\text { Canadian Cardiovascular Society Atrial fibrillation guidelines } \\
\text { 2010: prevention of stroke and systematic thromboembolism } \\
\text { in atrial fibrillation and flutter }{ }^{62}\end{array}$ & No specific guidance on how to detect AF. \\
\hline $\begin{array}{l}\text { Canadian Cardiovascular Society Atrial fibrillation guidelines } \\
\text { 2010: etiology and initial investigations }{ }^{63}\end{array}$ & $\begin{array}{l}\text { Does not deal specifically with the detection of AF but does } \\
\text { advise that a I2-lead ECG should be part of the baseline } \\
\text { evaluation for all patients with AF. }\end{array}$ \\
\hline $\begin{array}{l}\text { AHA/ASA Guidelines for the prevention of stroke in patients } \\
\text { with stroke or transient ischemic attack }(2011)^{64}\end{array}$ & No specific guidance on how to detect AF. \\
\hline
\end{tabular}


K Harris, D Edwards, J Mant

FIGURE 2 Summary of an evidence-based strategy for the detection of atrial fibrillation in the general

population

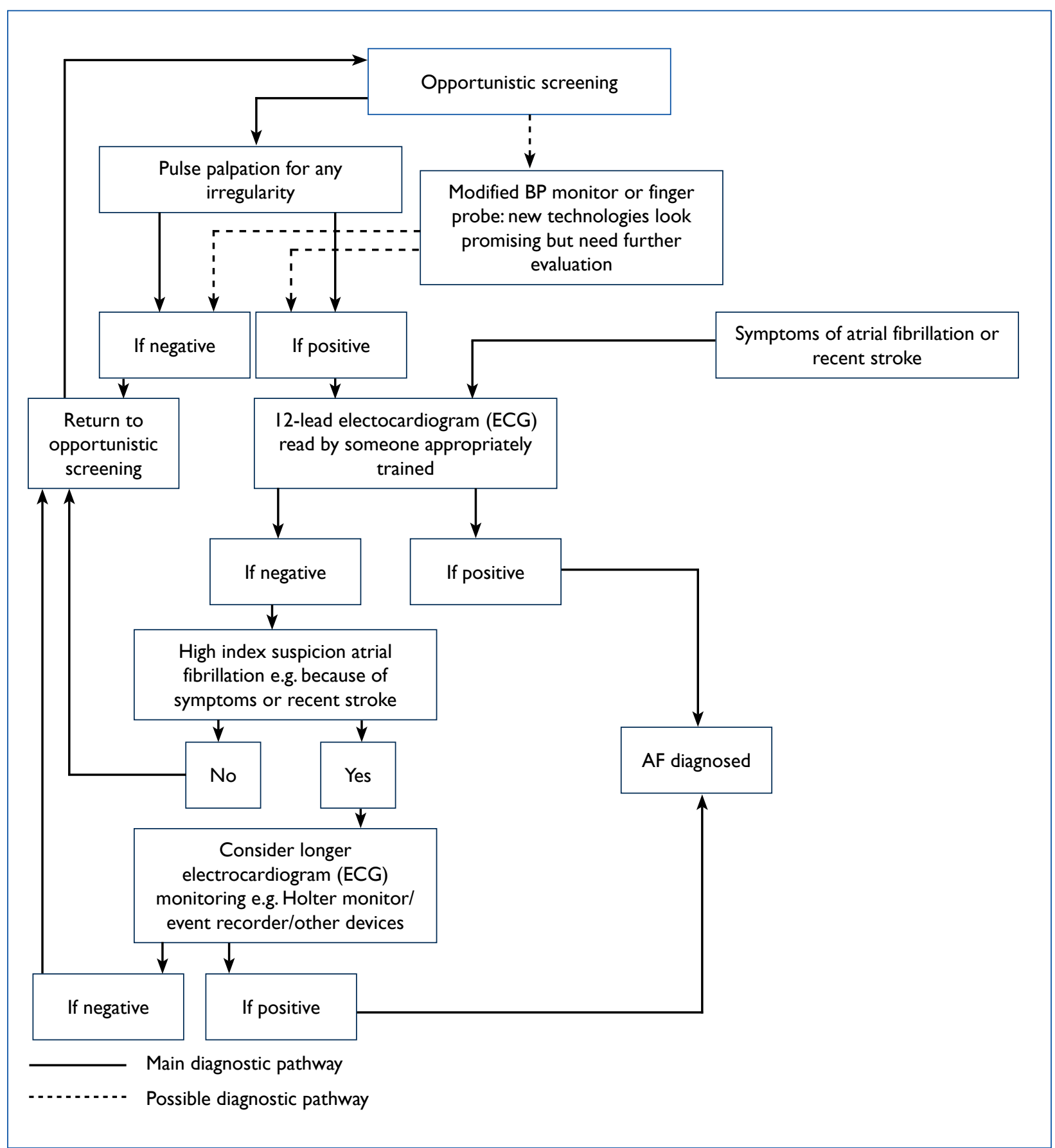




\section{REFERENCES}

I Mant J,Wade DT,Winner S. Health care needs assessment: stroke. In: Stevens A, Raftery J, Mant J, Simpson S, editors. Health care needs assessment: the epidemiologically based needs assessment reviews. Oxford: Radcliffe Medical Press; 2004. p. I4I-244.

2 National Collaborating Centre for Chronic Conditions. Atrial fibrillation: national clinical guideline for management in primary and secondary care. London: Royal College of Physicians; 2006.

3 Fitzmaurice DA, Hobbs FD, Jowett $S$ et al. Screening versus routine practice in detection of atrial fibrillation in patients aged 65 or over: cluster randomised controlled trial. BMJ 2007;335:383. http://dx.doi. org/I0.1 I 36/bmj.39280.660567.55

4 Wolf PA, Benjamin EJ, Belanger AJ et al. Secular trends in the prevalence of atrial fibrillation: the Framingham Study. Am Heart J 1996; | 31:790-5. http://dx.doi.org/10.1016/S0002-8703(96)90288-4

5 Furberg CD, Psaty BM, Manolio TA et al. Prevalence of atrial fibrillation in elderly subjects (the Cardiovascular Health Study). Am J Cardiol 1994; 74:236-4I. http://dx.doi.org//0.1016/0002-9149(94)90363-8

6 Wolf PA, Abbott RD, Kannel WB. Atrial fibrillation as an independent risk factor for stroke: the Framingham Study. Stroke 1991; 22:983-8. http://dx.doi.org//0.1 I6I/0I.STR.22.8.983

7 Dewar RI, Lip GY, Guidelines Development Group for the NICE clinical guideline for the management of atrial fibrillation. Identification, diagnosis and assessment of atrial fibrillation. Heart 2007; 93:25-8. http://dx.doi.org//0.1 136/hrt.2006.09986 I

8 Hart RG, Pearce LA, Aguilar MI. Meta-analysis: antithrombotic therapy to prevent stroke in patients who have nonvalvular atrial fibrillation. Ann Intern Med 2007; 146:857-67.

9 Connolly SJ, Ezekowitz MD, Yusuf S et al. Dabigatran versus warfarin in patients with atrial fibrillation. New Engl J Med 2009; 361: | |39-5 I. http://dx.doi.org//0.1056/NEJMoa090556 I

10 Flaker GC, Belew K, Beckman K et al. Asymptomatic atrial fibrillation: Demographic features and prognostic information from the Atrial Fibrillation Follow-up Investigation of Rhythm Management (AFFIRM) study. Am Heart J 2005; 149:657-63. http://dx.doi. org//0.1016/j.ahj.2004.06.032

I C Camm AJ, Kirchhof P, Lip GY et al. Guidelines for the management of atrial fibrillation: the Task Force for the Management of Atrial Fibrillation of the European Society of Cardiology (ESC). Eur Heart J 2010; 31:2369-429. http://dx.doi.org/10.1093/eurheartj/ehq278

12 van Walraven C, Hart RG, Singer DE et al. Oral anticoagulants vs aspirin in non-valvular atrial fibrillation: an individual patient metaanalysis. JAMA 2002; 288:244I-8. http://dx.doi.org//0.100I/ jama.288.19.244।

13 Hobbs FD, Fitzmaurice DA, Mant J et al. A randomised controlled trial and cost-effectiveness study of systematic screening (targeted and total population screening) versus routine practice for the detection of atrial fibrillation in people aged 65 and over.The SAFE study. Health Technol Assess 2005; 9:iii-iv, ix-x, I-74.

14 Morgan S, Mant D. Randomised trial of two approaches to screening for atrial fibrillation in UK general practice. $\mathrm{Br} J$ Gen Pract 2002; 52 : 373-4, 377-80.

15 Mant J, Fitzmaurice DA, Hobbs FD et al. Accuracy of diagnosing atrial fibrillation on electrocardiogram by primary care practitioners and interpretative diagnostic software: analysis of data from screening for atrial fibrillation in the elderly (SAFE) trial. BMJ 2007; 335:380. http://dx.doi.org//0.1 I36/bmj.39227.55 I7/3.AE

16 Doliwa PS, Frykman V, Rosenqvist M. Short-term ECG for out of hospital detection of silent atrial fibrillation episodes. Scand Cardiovasc J 2009; 43:163-8. http://dx.doi.org//0.1080//40 /7430802593435

17 Somerville S, Somerville J, Croft $P$ et al. Atrial fibrillation: a comparison of methods to identify cases in general practice. $\mathrm{Br} J$ Gen Pract 2000; 50:727-9.

18 Lewis M, Parker D, Weston C et al. Screening for atrial fibrillation: sensitivity and specificity of a new methodology. Br J Gen Pract 20I I; 61:38-9. http://dx.doi.org// 0.3399/bjgp I IX548956

19 Wiesel J,Wiesel D,Suri R et al.The use of a modified sphygmomanometer to detect atrial fibrillation in outpatients. Pacing Clinical Electrophysiol 2004; 27:639-43. http://dx.doi.org/I0. I I I //j.1540-8159.2004.00499.x
20 Wiesel J, Fitzig L, Herschman $Y$ et al. Detection of atrial fibrillation using a modified microlife blood pressure monitor. Am J Hypertens 2009; 22:848-52. http://dx.doi.org//0.1038/ajh.2009.98

21 Stergiou GS, Karpettas N, Protogerou A et al. Diagnostic accuracy of a home blood pressure monitor to detect atrial fibrillation. J Hum Hypertens 2009; 23:654-8. http://dx.doi.org//0.1038/ jhh.2009.5

22 Gregg RE, Zhou SH, Lindauer JM et al.Where do derived precordial leads fail? J Electrocardiol 2008;41:546-52. http://dx.doi.org//0.1016/j. jelectrocard.2008.07.018

23 Salerno SM,Alguire PC,Waxman HS. Competency in interpretation of I2-lead electrocardiograms: a summary and appraisal of published evidence. Ann Intern Med 2003; I38:75 I-60.

24 Anh D, Krishnan S, Bogun F. Accuracy of electrocardiogram interpretation by cardiologists in the setting of incorrect computer analysis.J Electrocardiol 2006; 39:343-5. http://dx.doi.org/10.1016/j. jelectrocard.2006.02.002

25 Mehall JR, Kohut RM Jr, Schneeberger EW et al. Absence of correlation between symptoms and rhythm in 'symptomatic' atrial fibrillation. Ann Thorac Surg 2007; 83:2118-21. http://dx.doi. org//0.1016/j.athoracsur.2007.02.084

26 Reiffel JA, Schwarzberg R, Murry M. Comparison of autotriggered memory loop recorders versus standard loop recorders versus 24-hour Holter monitors for arrhythmia detection. Am J Cardiol 2005; 95:1055-9. http://dx.doi.org/10.1016/j.amjcard.2005.01.025

27 Kinlay S, Leitch JW, Neil A et al. Cardiac event recorders yield more diagnoses and are more cost-effective than 48-hour Holter monitoring in patients with palpitations. A controlled clinical trial. Ann Intern Med 1996; 124:16-20.

28 Hindricks G, Pokushalov E, Urban L et al. Performance of a new leadless implantable cardiac monitor in detecting and quantifying atrial fibrillation: Results of the XPECT trial.Circ Arrhythm Electrophysiol 20I0; 3:14I-7. http://dx.doi.org/I0.I I6I/CIRCEP.109.877852

29 Hohnloser SH, Pajitnev D, Pogue J et al. Incidence of stroke in paroxysmal versus sustained atrial fibrillation in patients taking oral anticoagulation or combined antiplatelet therapy: an ACTIVE W substudy.JAm Coll Cardiol 2007;50:2 156-61.http://dx.doi.org/10.1016/j. jacc.2007.07.076

30 Healey JS, Connolly SJ, Gold MR et al. Subclinical atrial fibrillation and the risk of stroke. N Engl J Med 2012; 366:120-9. http://dx.doi. org/ I0.1056/NEJMoal I 05575

31 ISD Scotland National Statistics. Estimated number of patients seen/not seen in Scotland by either a general practitioner (GP) or practice nurse [Internet]. Edinburgh: ISD Scotland; 20I I [cited 20II Dec I4].Available from: http://www.isdscotland.org/Health-Topics/General-Practice/ Publications/201 I-I I-29/PTI_NovII_FiglO_PyramidChart.xls

32 QResearch and The Health and Social Care Information Centre. Trends in consultation rates in general practice 1995// 996 to 2008/2009: analysis of the QResearch database [Internet]. Leeds:The Information Centre; 2009 [cited 201 I Dec 14]. Available at: http://www.ic.nhs.uk/ webfiles/publications/gp/Trends_in_Consultation_Rates_in_General_ Practice_1995_96_to_2008_09.pdf

33 Sudlow $M$, Rodgers $H$, Kenny RA et al. Identification of patients with atrial fibrillation in general practice: a study of screening methods. BMJ 1998; 317:327-8. http://dx.doi.org//0.1 I36/bmj.317.7154.327

34 Cooke G, Doust J, Sanders S. Is pulse palpation helpful in detecting atrial fibrillation: a systematic review.J Fam Pract 2006; 55:130-4.

35 Poon K, Okin PM, Kligfield P. Diagnostic performance of a computer-based ECG rhythm algorithm. J Electrocardiol 2005; 38:235-8. http://dx.doi.org// 0.1016/j.jelectrocard.2005.01.008

36 Gunalp M,Atalar E, Coskun F et al. Holter monitoring for 24 hours in patients with thromboembolic stroke and sinus rhythm diagnosed in the emergency department. Adv Ther 2006; 23:854-60. http://dx.doi. org/ I0.1007/BF02850206

37 Tagawa M, Takeuchi S, Chinushi $M$ et al. Evaluating patients with acute ischemic stroke with special reference to newly developed atrial fibrillation in cerebral embolism. Pacing Clin Electrophysiol 2007; 30:| | 2|-8. http://dx.doi.org//0.1 I I //j. I540-8159.2007.00823.x 
K Harris, D Edwards, J Mant

38 Douen AG, Pageau N, Medic S. Serial electrocardiographic assessments significantly improve detection of atrial fibrillation 2.6-fold in patients with acute stroke. Stroke 2008; 39:480-2. http://dx.doi.org/10.1161/ STROKEAHA. 107.492595

$39 \mathrm{Yu} \mathrm{EH}$, Lungu C, Kanner RM et al. The use of diagnostic tests in patients with acute ischemic stroke. J Stroke Cerebrovasc Dis 2009; I8: 178-84.http://dx.doi.org//0.1016/j.jstrokecerebrovasdis.2008.09.004

40 Alhadramy O, Jeerakathil TJ, Majumdar SR et al. Prevalence and predictors of paroxysmal atrial fibrillation on Holter monitor in patients with stroke or transient ischemic attack. Stroke 2010 4I:2596-600. http://dx.doi.org/ I0. I I6I/STROKEAHA. 109.570382

4I Lazzaro MA, Krishnan K, Prabhakaran S. Detection of atrial fibrillation with concurrent Holter monitoring and continuous cardiac telemetry following ischemic stroke and transient ischemic attack. J Stroke Cerebrovasc Dis 2012; 21:89-93. Epub 2010 Jul 24 http://dx.doi. org/10.1016/j.jstrokecerebrovasdis.2010.05.006

42 Barthélémy JC, Féasson-Gérard S, Garnier $P$ et al.Automatic cardiac event recorders reveal paroxysmal atrial fibrillation after unexplained strokes or transient ischaemic attacks. Ann Noninvasive Electrocardiol 2003; 8: 194-9. http://dx.doi.org/ 10.1046/j. I 542-474X.2003.08305.x

43 Jabaudon D, Sztajzel J, Sievert K. Usefulness of ambulatory 7-day ECG monitoring for the detection of atrial fibrillation and flutter after acute stroke and transient ischemic attack. Stroke 2004; 35:1647-5I. http://dx.doi.org//0.1 I6I/0 I.STR.0000 I3 1269.69502.d9

44 Koudstaal PJ, van Gijn J, Klootwijk AP et al. Holter monitoring in patients with transient and focal ischemic attacks of the brain. Stroke 1986; 17:192-5. http://dx.doi.org/10.1 161/0I.STR.17.2.192

45 Schaer BA, Zellweger MJ, Cron TA et al. Value of routine holter monitoring for the detection of paroxysmal atrial fibrillation in patients with cerebral ischemic events. Stroke 2004; 35:e68-70. http://dx.doi.org/10.I I6I/0I.STR.0000 I I 7568.07678.4B

46 Stahrenberg R,Weber-Kruger M, Seegers J et al. Enhanced detection of paroxysmal atrial fibrillation by early and prolonged continuous Holter monitoring in patients with cerebral ischemia presenting in sinus rhythm. Stroke 2010; 41:2884-8. http://dx.doi.org/10.1161/ STROKEAHA.II 0.591958

47 Rem JA, Hachinski VC, Boughner DR et al. Value of cardiac monitoring and echocardiography in TIA and stroke patients. Stroke 1985; 16:950-6. http://dx.doi.org//0.1 I6I/0I.STR.16.6.950

48 Hornig CR, Haberbosch W, Lammers C et al. Specific cardiological evaluation after focal cerbral ischemia. Acta Neurol Scand 1996; 93:297-302. http://dx.doi.org/I0. I I I/j. I600-0404.1996.tb00524.x

49 Shafqat S, Kelly PJ, Furie KL. Holter monitoring in the diagnosis of stroke mechanism. Intern Med J 2004; 34:305-9. http://dx.doi. org/I0.1 I I I/j. I 444-0903.2004.00589.x

50 Rizos T, Rasch C, Jenetzky E et al. Detection of paroxysmal atrial fibrillation in acute stroke patients. Cerebrovasc Dis 2010;30:410-7. http://dx.doi.org/I0.I I59/000316885

5I Schuchert A, Behrens G, Meinertz T. Impact of long-term ECG recording on detection of paroxysmal atrial fibrillation in patients after an acute ischemic stroke. Pacing Clin Electrophysiol 1999; 22: 10824. http://dx.doi.org//0.1 I I I/j. I540-8159.1999.tb00574.x

52 Kamel H, Lees KR, Lyden PD et al. Delayed detection of atrial fibrillation after ischemic stroke.J Stroke Cerebrovasc Dis 2009; 18:4537. http://dx.doi.org/10.1016/j.jstrokecerebrovasdis.2009.01.012

53 Gaillard N, Deltour S, Vilotijevic B et al. Detection of paroxysmal atrial fibrillation with transtelephonic EKG in TIA or stroke patients. Neurology 2010; 74:1666-70. http://dx.doi.org//0.12/2/ WNL.0b0 I 3e3/8Ie0427e
54 Tayal AH, Tian M, Kelly KM et al. Atrial fibrillation detected by mobile cardiac outpatient telemetry in cryptogenic TIA or stroke. Neurology 2008; 71:1696-1701. http://dx.doi.org/10.1212/0I. wnl.0000325059.863 I3.3।

55. Elijovich L, Josephson SA, Fung GL et al. Intermittent atrial fibrillation may account for a large proportion of otherwise cryptogenic stroke: a study of 30-day cardiac event monitors. J Stroke Cerebrovasc Dis 2009; 18:185-9. http://dx.doi.org/10.1016/j. jstrokecerebrovasdis.2008.09.005

56 Dion F, Saudeau D, Bonnaud I et al. Unexpected low prevalence of atrial fibrillation in cryptogenic ischemic stroke: a prospective study. J Interv Card Electrophysiol 20 10; 28: I01-7. http://dx.doi.org/10.1007/ sl0840-010-9485-5

57 Fuster V, Rydén LE, Asinger RW et al.ACC/AHA/ESC guidelines for the management of patients with atrial fibrillation. A report of the American College of Cardiology/American Heart Association Task Force on Practice Guidelines and the European Society of Cardiology Committee for Practice Guidelines and Policy Conferences (Committee to develop guidelines for the management of patients with atrial fibrillation) developed in collaboration with the North American Society of Pacing and Electrophysiology. Eur Heart / 200 I; 22: I 852-923. http://dx.doi.org/ 10.1053/euhj.2001.2983

58 Scottish Intercollegiate Guidelines Network (SIGN). Cardiac arrhythmias in coronary heart disease. A national clinical guideline [Internet]. Edinburgh: SIGN; 2007 [cited $201 \mathrm{I}$ Dec 5]. Available from: www.sign.ac.uk/pdf/sign94.pdf

59 Scottish Intercollegiate Guidelines Network (SIGN). Management of patients with stroke or TIA: assessment, investigation, immediate management and secondary prevention. A national clinical guideline [Internet]. Edinburgh: SIGN; 2008 [cited 20II Dec 5]. Available from: www.sign.ac.uk/pdf/sign l08.pdf

60 European Stroke Organisation (ESO) Executive Committee and the ESO Writing Committee. Guidelines for management of ischaemic stroke and transient ischaemic attack 2008. Cerebrovasc Dis 2008; 25:457-507. http://dx.doi.org/10.1 I59/000 I31083

6 I National Collaborating Centre for Chronic Conditions. Stroke: national clinical guideline for diagnosis and initial management of acute stroke and transient ischaemic attack (TIA) [Internet]. London: Royal College of Physicians; 2008 [cited 201 I Dec 5]. Available from: www. nice.org.uk/nicemedia/pdf/CG68FullGuideline.pdf

62 Cairns JA, Connolly S, McMurtry S et al. Canadian Cardiovascular Society atrial fibrillation guidelines 2010: prevention of stroke and systemic thromboembolism in atrial fibrillation and flutter. Can J Cardiol 20 I I;27:74-90.http://dx.doi.org/10.1016/j.cjca.20 I 0.II.007

63 Healey JS, Parkash R, PollakT et al. Canadian Cardiovascular Society atrial fibrillation guidelines 2010: etiology and initial investigations. Can J Cardiol 201 I; 27:3 I-7. http://dx.doi.org/I0.1016/j.cjca.2010.11.015

64 Furie KL, Kasner SE, Adams RJ et al. Guidelines for the prevention of stroke in patients with stroke or transient ischemic attack: a guideline for healthcare professionals from the American Heart Association/American Stroke Association. Stroke 20I I; 42: 227-76. http://dx.doi.org//0.1 I6I/STR.0b0 I 3e3 I8If7d043 